\title{
Contribution of the oxidative and nitrosative stresses to the development of placental malaria and the consequences for the fetus
}

\author{
Contribuição dos estresses oxidativo e nitrosativo para o desenvolvimento da malária \\ placentária e as consequências para o feto
}

\author{
Contribución de las tensiones oxidativas y nitrosativas al desarrollo de la malaria \\ placentaria y las consecuencias para el feto.
}

\begin{abstract}
Kassyo Lenno Sousa Dantas ${ }^{1 *}$, Anna Beatriz da Silva Sousa Mota ${ }^{1}$, Cristiane Santos Silva e Silva Figueiredo ${ }^{1}$, Michael Ranniery Garcia Ribeiro ${ }^{1}$, Adriana dos Santos Oliveira ${ }^{1}$, Arannadia Barbosa Silva ${ }^{1}$, Júlio Evangelista de Lucena ${ }^{1}$, Wermerson Assunção Barroso ${ }^{1}$, Milena Sousa Freitas ${ }^{1}$, Domingos Magno Santos Pereira'.
\end{abstract}

\begin{abstract}
Objective: To describe the role of oxidative/nitrosative stresses in the pathogenesis of placental malaria and complications for the fetus. Bibliographic review: Placental malaria results from the sequestration of erythrocytes infected by Plasmodium falciparum in the blood microcirculation of the placental interventional spaces, leading to the infiltration of activated leukocytes in these sites, with subsequent production of cytokines and chemokines. These mediators, associated with phagocytosis of parasites and infected cells, activate the oxidative/nitrosative stresses pathways, producing free radicals and oxidation/nitration molecules, which act by attacking compounds of the cell structure of both the parasite and the host cells, causing damage to the integrity of the placental barrier and leading to insufficiency of the placenta to support fetal development. Final considerations: Therefore, we conclude that the immune response and oxidative/nitrosative stresses play an important role not only in the defense of the patient (reducing parasitaemia), but also in the progression of the disease and placental invasion, leading to serious changes and complications to the fetus.
\end{abstract}

Keyword: Malaria, Placental, Stress, Oxidative, Nitrosative.

\section{RESUMO}

Objetivo: Descrever o papel dos estresses oxidativo e nitrosativo na patogênese da malária placentária e as complicações para o feto. Revisão bibliográfica: A malária placentária resulta do sequestro de eritrócitos infectados pelo Plasmodium falciparum na microcirculação sanguínea dos espaços intervilares da placenta, levando a infiltração de leucócitos ativados nesses locais, com posterior produção de citocinas e quimiocinas. Esses mediadores, associados a fagocitose de parasitas e células infectadas, ativam as vias dos estresses oxidativo e nitrosativo, com produção de radicais livres e moléculas de oxidação/nitração, as quais atuam atacando compostos da estrutura celular tanto do parasita quanto de células do hospedeiro, causando danos à integridade da barreira placentária e levando à insuficiência da placenta para o aporte do desenvolvimento fetal. Considerações finais: Portanto, concluímos que a resposta imune e o estresse oxidativo/nitrosativo desempenham papeis importante não apenas na defesa do paciente (redução da parasitemia), mas também na progressão da doença e invasão placentária, levando a alterações e complicações sérias ao feto.

Palavras-chave: Malária, Placentária, Estresse, Oxidativo, Nitrosativo.

\section{RESUMEN}

Objetivo: Describir el papel del estrés oxidativo/nitrosativo en la patogénesis de la malaria placentaria y las complicaciones para el feto. Revisión bibliográfica: Malaria placentaria es el resultado del secuestro de

${ }^{1}$ Universidade CEUMA (UNICEUMA), Imperatriz - MA. *E-mail: kassyolenno@outlook.com 
eritrocitos infectados por Plasmodium falciparum en la microcirculación de los espacios intervencionistas placentarios, lo que conduce a la infiltración de leucocitos activados en estos sitios, con la posterior producción de citocinas/quimiocinas. Estos mediadores, asociados con la fagocitosis de parásitos/células infectadas, activan las vías de estrés oxidativo/nitrosativo, produciendo radicales libres y moléculas de oxidación/nitración, que actúan atacando compuestos en la estructura celular tanto del parásito como de las células huésped, causando daño a la integridad de la barrera placentaria y dando lugar a una placenta insuficiente para el desarrollo fetal. Consideraciones finales: Entonces, concluimos que la respuesta inmune y el estrés oxidativo/nitrosativo juegan un papel importante no solo en la defensa del paciente (reducción de la parasitemia), sino también en la progresión de la enfermedad (invasión placentária), lo que conduce a complicaciones graves para el feto.

Palabras clave: Malaria, Placentaria, Estrés, Oxidativo, Nitrosativo.

\section{INTRODUCTION}

Malaria is an protozoan infectious disease caused by a blood parasite (systemic infection), which exhibits high mortality affecting 216 million people worldwide, reaching approximately 429,000 deaths in 2015 . It is transmitted through the bite of the female infected mosquitoes of the Anopheles genus, which introduce the parasites into the host's circulatory system; these parasites, in turn, migrate to liver cells for reproduction and maturation. The signs and symptoms appear between the days 8 and 24 post-infection and may vary from organism to organism; these include headaches, fever, chills, joint pain, vomiting, hemolytic anemia, jaundice, hemoglobin in the urine, retinal lesions and seizures (WHO, 2015). According to the World Health Organization, malaria is cause of great morbidity and mortality, being the protozoan infectious disease that kills the most in the world; it is important to emphasize that such data may be even more expressive, since underreporting cases still occupies a prominent role in these countries (WHO, 2015).

In Brazil, the cases of malaria are mainly located in the region known as Legal Amazon, which comprises the states of Acre, Amapá, Amazonas, Maranhão, Mato Grosso, Pará, Rondônia, Roraima and Tocantins and represents more than $99 \%$ of the reported cases (LAPOUBLE OMM, et al., 2015). Furthermore, pregnant women tend to be more affected by malaria, since their immune response are compromised by pregnancy, allowing the better development of the parasite in the organism and, thus, contributing to the evaluation of the disease for cases of severe malaria, with commitment of several organs (OLUWAGBEMIGA A, et al., 2018).

Severe malaria exhibit high mortality rate even with the adequate treatment and when left untreated is fatal; in fact, Plasmodium falciparum, the etiological agent responsible for severe malaria, already present resistance for the treatment with chloroquine and artemisin (RAMANI S, et al., 2016).

Among the most frequent clinical manifestations of severe malaria, it is possible to highlight cerebral, pulmonary and placental malaria (MUBARAKI MA, et al., 2017; SHARMA L, et al., 2012; ELZEIN F, et al., 2017). In this context, oxidative/nitrosative stresses and the production of reactive oxygen and nitrogen species (ROS and RNS, respectively) during the immune response to $P$. falciparum play an important role in the development and prognostic of the disease (HAWKES M, et al., 2011; MEGNEKOU R, et al., 2015).

Thus, this article aimed to describe the role of the oxidative and nitrosative stresses in the pathogenesis of the placental malaria and the complications for the fetus.

\section{BIBLIOGRAPHIC REVIEW}

\section{Immune response in malaria}

The immune response to malaria starts with the phagocytosis of the parasites in the liver and blood stages mainly by monocytes and tissue macrophages. This cells, when enter in contact with $P$. falciparum trigger an excessive production of inflammatory mediators such as cytokines and chemokines which act by activating and recruiting more immune cells to the site of the infection, in an attempt to destroy the invading pathogen and promote the repair of the tissue damage (PERKINS DJ, et al., 2011). 
The cytokine profile produced in response to the Plasmodium spp infection already was demonstrated, being Tumor Necrosis Factor-alpha (TNF- $\alpha$ ), Interferon (IFN) and Interleukin-12 (IL-12) the majors compounds of the Th1 pattern (or proinflammatory cytokines) and Interleukin-4 (IL-4), Interleukin-5 (IL-5), Interleukin-10 (IL-10) and Transforming Growth Factor-beta (TGF- $\beta$ ) the major ones from the anti-inflammatory Th2 pattern (BAKIR HY, et al., 2011). The phagocytosis and release of pro-inflammatory cytokines promote the increase of reactive oxygen species (ROS) and reactive nitrogen species (RNS), generating the oxidative and nitrosative stresses. The oxidative and nitrosative stresses can be defined as the imbalance among the production of pro and antioxidant molecules, conducting the cells to oxidative/nitrosative damages, in response to a persistent infectious or inflammatory stimulus (RANI V, et al., 2016).

Previous studies already demonstrated the vulnerability of the Plasmodium spp to oxidative (and nitrosative) products. However, ROS and RNS in some cases contribute to the invasion of organs by the parasite e subsequent aggravation of the pathogenesis (AL-SHAEBI EM, et al., 2017). Furthermore, infected red blood cells are frequently sequestered in the capillaries of some organs, promoting endothelial lesions, making possible the spread of the parasites to various organs, such as lung, placenta and brain (MUBARAKI MA, et al., 2017; MUBARAKI MA, et al., 2017). Contributing directly to the progression of malaria to severe malaria (ELZEIN F, et al., 2017).

\section{Free radicals and oxidant molecules in malaria infection}

In a Plasmodium spp infection, the oxidative stress occurs in response to the phagocytosis of the parasites in the liver and circulation by neutrophils and monocytes/macrophages for parasites destruction into the phagolysosomes of these cells. The free radicals are highly unstable and reactive molecules that exhibit one or more unpaired electrons in the last electronic layer. They are formed mainly through oxidation-reduction reactions, being able to react with several biological molecules and, still, are related to cells and parasites death (MUBARAKI MA, et al., 2017).

Free radicals and oxidant molecules formed in oxidative and nitrosative stresses attack biological molecules to get their stability. These molecules, know as reactive oxygen and nitrogen species (ROS and RNS, respectively), when in contact with Plasmodium spp and host's cells, react with their fatty acids from membranes, proteins and nucleic acids, triggering a process called lipid peroxidation, as illustrated in the Figure 1. The increase of these compounds can cause tissue lesions and, therefore, the organism present antioxidant defenses, in which eliminate the excess of these free radicals and oxidizing molecules (PERCÁRIO S, et al., 2012).

Figure 1 - Effect of the ROS (reactive oxygen species) and RNS (reactive nitrogen species) production on both parasites (Plasmodium) and host cells, with following cellular death.

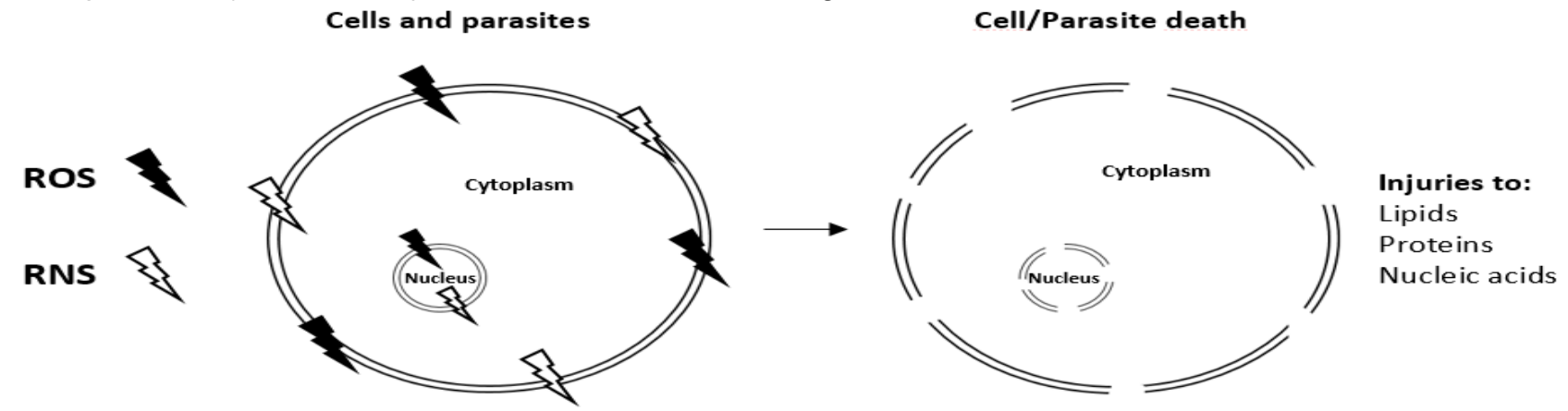

Source: Dantas KLS, et al., 2020.

Among the major reactive species produced in response to infections and inflammatory diseases, we can highlight those derived from reactive oxygen species, such as superoxide anion (O2-), hydroxyl $\left(\mathrm{OH}^{-}\right)$, hydrogen peroxide $\left(\mathrm{H}_{2} \mathrm{O}_{2}\right)$, etc; and those from reactive nitrogen species such as nitric oxide (NO), among others. Furthermore, ROS and RNS can react with each other to form the peroxynitrite (ONOO-), a very powerful reactive free radical (BISWAS S, et al., 2017). 


\section{Reactive oxygen species (ROS)}

ROS are chemicals compounds derived from the reduction of oxygen by Reduced Nicotinamide Adenine Dinucleotide Phosphate (NADPH) oxidase (NOX) enzyme. Among the main ROS produced in human, we can cite the superoxide anion $\left(\mathrm{O}_{2}^{-}\right)$and hydrogen peroxide $\left(\mathrm{H}_{2} \mathrm{O}_{2}\right)$, in which can contribute to the formation of other ones. ROS participate of the pathogenesis and worsening of several inflammatory and infectious diseases, such as the transition from malaria to placental malaria, causing cell damage due to reactions with proteins and lipids of cell membranes and even with nucleic acids (WARNATSCH A, et al., 2017; ELZEIN F, et al., 2017).

In malaria the production of ROS is observed in response to the activation of neutrophils and macrophages by specific or particulate soluble inflammatory mediators or pathogen-associated molecular pattern (PAMP), which are recognized by receptors present on the surface of these cells, that become activated and start the fighting against the Plasmodium (PERKINS DJ, et al., 2011).

In response to infections part of the molecular oxygen (dioxygen, $\mathrm{O}_{2}$ ) of mitochondrial respiration during oxidative phosphorylation are reduced to superoxide anions $\left(\mathrm{O}^{2-}\right)$; NADPH complex acts as an electron donor and the enzyme flavocytochrome oxidase b558 (NADPH Component) mediates this reaction. The superoxide formed is then converted to $\mathrm{H}_{2} \mathrm{O}_{2}$ by the enzyme superoxide dismutase (SOD), both $\mathrm{O}^{2-}$ and $\mathrm{H}_{2} \mathrm{O}_{2}$ can posteriorly form hydroxyl radical, as shown in the Figure 2 (SIES H, et al., 2017).

Figure 2 - Production of reactive oxygen species (ROS). NADPH oxidase acts as an electron donor, forming the superoxide anion $\left(\mathrm{O}_{2}{ }^{-}\right)$. This is then, converted to hydrogen peroxide $\left(\mathrm{H}_{2} \mathrm{O}_{2}\right)$ by the action of the superoxide dismutase (SOD). Also, through the reactions of Haber-Weiss (using the superoxide anion) and Fenton (using hydrogen peroxide), the hydroxyl radical, also related to tissue injuries, is produced.

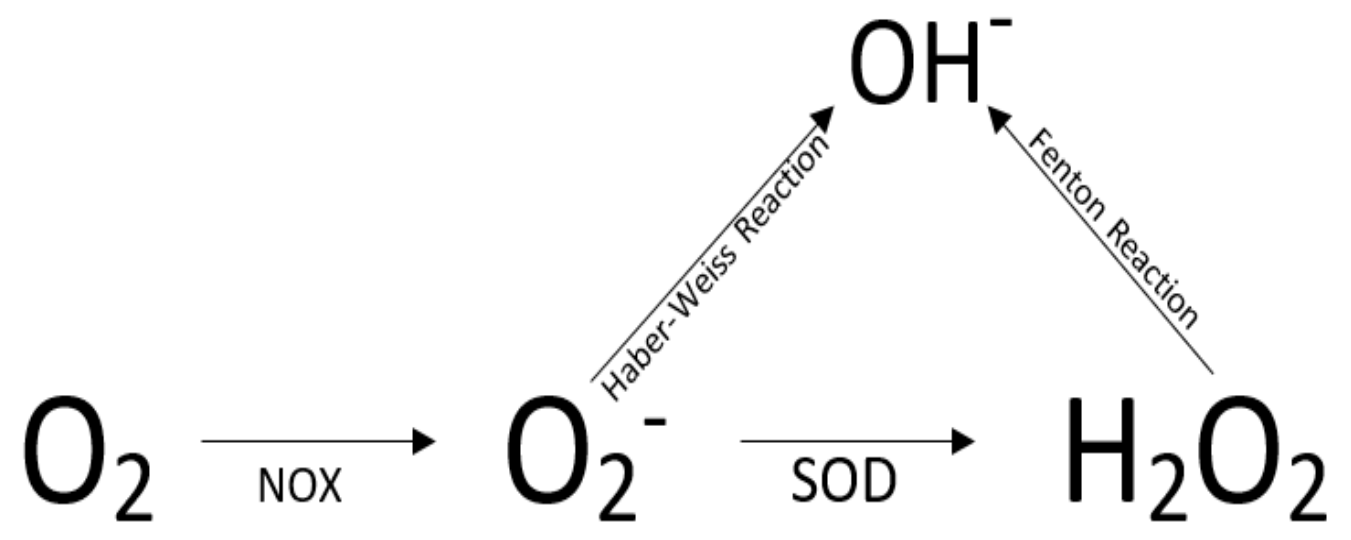

Source: Dantas KLS, et al., 2020.

$\mathrm{H}_{2} \mathrm{O}_{2}$ exerts several biological functions in the human organism, among them, acts as an important signaling molecule, mediate phagocytosis, it is a cytotoxic agent in the defense system and also, in some cases, can cause or aggravate diseases (SIES H, et al., 2017). In malaria $\mathrm{H}_{2} \mathrm{O}_{2}$ plays an important role in the control of the parasitaemia by killing the parasites, on the other hand, also cause oxidation of host cell's components, destructing barriers in specific sites of the blood flow where there are infected red blood cells (iRBC) sequestrated by the endothelium in the microcirculation of organs, such as in placenta (MEGNEKOU R, et al., 2015). After the death of the Plasmodium, the production of ROS have to be stopped in order to avoid more damages to the host cells.

\section{Nitrogen reactive species (RNS)}

In infections caused by Plasmodium spp. cells of the immune system mainly neutrophils and macrophages, after contact with the pathogen, recognize specific parasite proteins and get activated, after this, the immune 
response against these microorganisms is triggered; after recognition, the production of cytokines and other inflammatory mediators, activate the pathways of the nitric oxide synthesis as a complement of the immune response for killing the parasite and signaling the inflammatory process, also playing important roles in the vascular tone (SOBOLEWSKI P, et al., 2005).

The nitric oxide synthase (NOS) enzyme is the molecule responsible for nitric oxide (NO) production. For this, the synthesis of NO involves two steps: 1) the hydroxylation of one of the guanidinium nitrogens of the Larginine to generate NG-hydroxy-L-arginine (NHA), reaction mediated by the complex NADPH and $\mathrm{O}_{2}$ and probably involves the heme complex of the NOS; and 2) the NHA is converted into nitrite (NO) and L-citrulline, as shown in Figure 3 (CORBETT Y, et al., 2018).

Figure 3 - Formation of nitric oxide from the amino acid L-arginine through the action of the enzyme inducible nitric oxide synthase (iNOS).

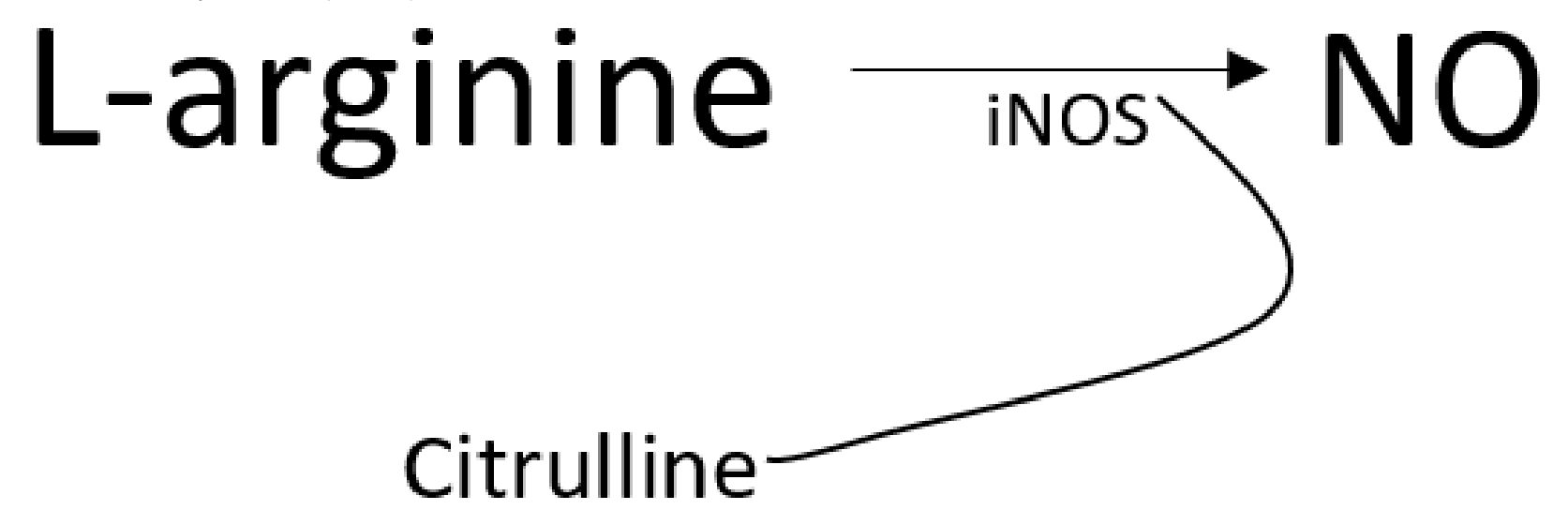

Source: Dantas KLS, et al., 2020.

There are currently three known NOS isoforms and they have been described based on the genetic characteristics of each other, being two constitutive isoforms (cNOS), which are sensitive to calcium stimulation, called endothelial nitric oxide synthase (eNOS) and neuronal nitric oxide synthase (nNOS ) and are mainly related to physiological functions of NO, such as vascular tone and neurotransmission. A third isoform of this enzyme is called inducible nitric oxide synthase (iNOS) and is mainly related to the pathophysiological production of nitric oxide, especially in infectious/inflammatory diseases, such as malaria (HIRST DG, et al., 2011; POILOS TL, et al., 2017).

cNOSs are responsible for producing small concentrations of $\mathrm{NO}$ (nano/ picomols) and their activation are dependent on the interaction with calmodulin and is controlled by $\mathrm{Ca}^{2+}$ levels. iNOS is mainly present in macrophages, is calcium dependent and its activity is induced by cytokines, such as tumor necrosis factoralpha (TNF- $\alpha$ ), interleukin-1 (IL-1) and interferon-gamma (IFN- Y), besides being also induced by parasitic structural components, such as membrane proteins present in bacteria and other microorganisms. iNOS is responsible for the largest NO production and its synthesis lasts until the complete depletion of $L$-arginine or cell death (SOBOLEWSKI P, et al., 2005; HIRST DG, et al., 2011).

NO plays a vast role in the organism performing a variety of physiological processes, such as cell signaling, neurotransmission, vascular tone control, blood pressure control, muscle contraction and cardiac activity, in addition, it also acts on innate immunity, exhibiting microbicidal potential due to its ability to form reactive nitrogen species, compounds toxic for both microorganisms and host cells, as they react with various cellular components (as lipids and proteins) and promote cell death (HIRST DG, et al., 2011).

In higher concentrations NO contribute to tissue injure and still, may react with $\mathrm{H}_{2} \mathrm{O}_{2}$ to form peroxynitrite (ONOO-) a powerful and potent free radical related to enhanced oxidative damage, as shown in Figure 4 (ISLAM BU, et al., 2015). 
Figure 4 - Overview of the oxidative and nitrosative stresses. Note that, ROS and RNS react to form peroxynitrite (ONOO-) a very powerful free radical related to enhanced parasite and tissue destruction in cases of malaria/severe malaria. RNS can cause both oxidation and nitration of lipids, proteins and nucleic acids.

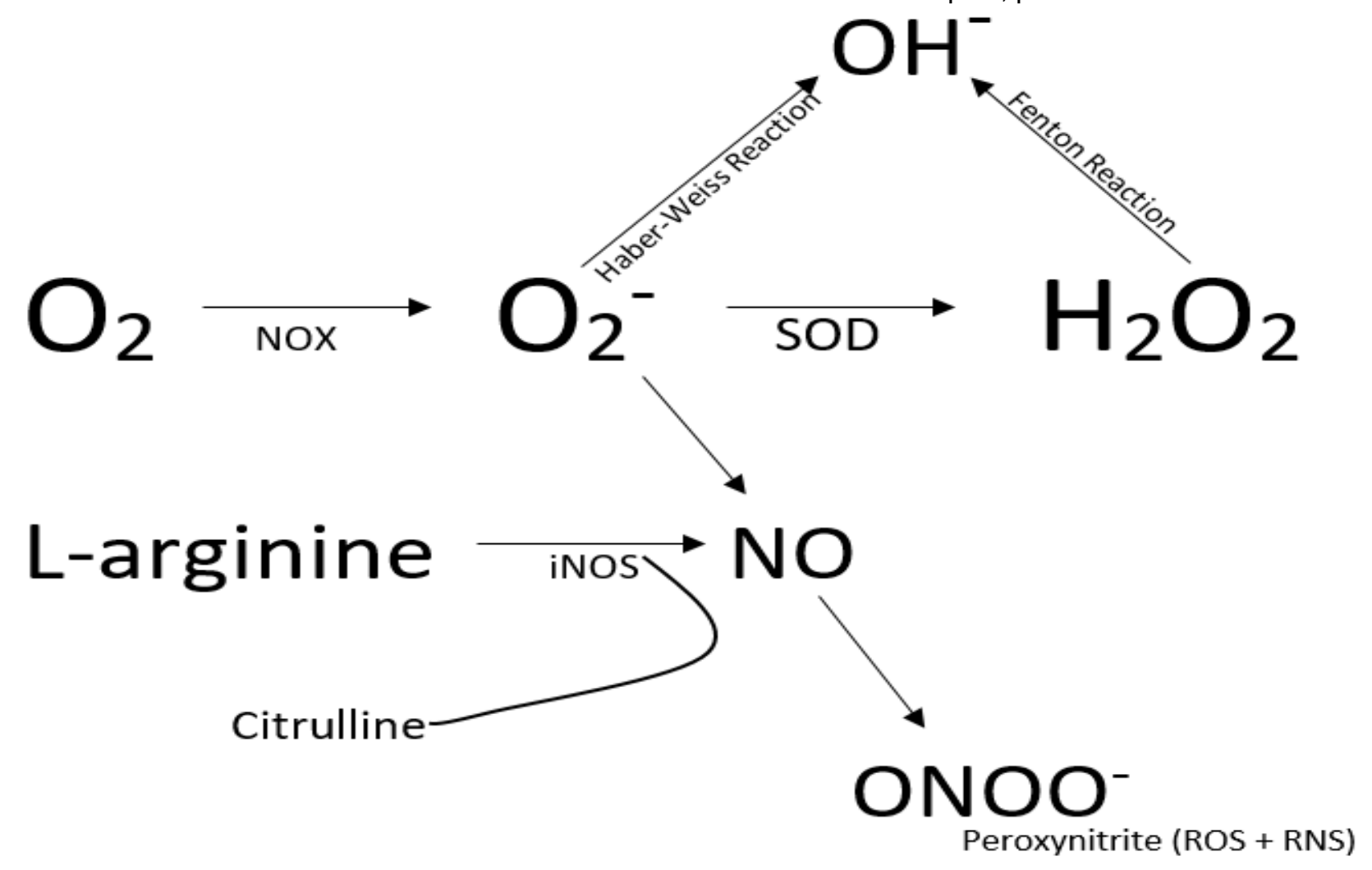

Source: Dantas KLS, et al., 2020.

In malaria, the role of NO is still contradictory, as there is both good and bad evidence about its effects in patients infected with Plasmodium spp. Studies demonstrate that, in high concentrations NO acts to combat microorganisms and tumor cells. On the other hand, it has also been shown to be related to the development of diseases such as septic shock, cardiovascular and autoimmune diseases (HIRST DG, et al., 2011). Yet, it is related to injuries to biological barriers through the oxidation/nitration of its components, allowing the spread of parasites to different organs, such in placental malaria (BERTOLDO BJ, et al., 2016).

In cases of death of the parasites, the organism needs to deal with the excess of reactive species and free radicals to avoid more oxidative damage. For this, our body has a powerful antioxidant system formed by different enzyme systems, discussed in the next session.

\section{Antioxidant host protection}

In healthy individuals the production of ROS and RNS is controlled by the enzymatic and non-enzymatic antioxidant defense system. An antioxidant substance is one that is able to react with free radicals, donating electrons and chemically stabilizing these compounds, without producing reactive metabolites. The enzymatic antioxidant system is formed by different enzymes and system of enzymes, such as superoxide dismutase (SOD), catalase (CAT), glutathione and thioredoxin (CANLI EG, et al., 2017; TURK BR, et al., 2017).

The superoxide dismutase (SOD) is a metalloenzyme responsible for catalyzing the superoxide ions dismutation reaction into hydrogen peroxide (a less reactive compound), being an important protein in the antioxidant system in the most tissues exposed to ROS. SOD is present in three distinct isoforms and its classification depends on the metal ion to which it binds and the tissue where it is found. They are the citoplasmatic Cu/ZnSOD (SOD1), mitochondrial MnSOD (SOD2) and extracellular Cu/ZnSOD (SOD3) (HERNANDEZ SD, et al., 2017). 
Catalase is another important enzyme in the cellular antioxidant defense system, it belongs to the subclass of enzymes called oxidoreductases; it is a homotetramedic protein of $240 \mathrm{kDa}$ present mainly in peroxisome, however, it can also be found in the cytoplasm and nucleus of the cells, mainly in the red blood and hepatic cells and is directly related to the metabolism of high concentration of hydrogen peroxide previously formed by SOD, in water and molecular oxygen, also preventing the formation of hydroxyl radicals $\left(\mathrm{OH}^{-}\right)$, which are quite reactive against membrane compounds. The activity of CAT is increased at high concentrations of hydrogen peroxide, while low concentrations of it are controlled by the glutathione system (GLORIEUX G and CALDERON PB, 2017).

Reduced glutathione (GSH) is the main antioxidant molecule produced by the cells. GSH exhibit a neutralizing action for these radicals, inactivating them and protecting cells against tissues injuries, such as those occurred by lipid and protein peroxidation. In the cells, glutathione can be found under three isoforms, reduced (monomeric, or GSH), oxidized (dimeric, or GSSG) or conjugated (GS-R), being the reduced the more prevalent in healthy tissues. Among the substances removed by glutathione system, it is included the aromatic, aliphatic, epoxides, heterocyclic and alicyclic, aliphatic and halogenated aromatic compounds (FORMAN HJ, et al., 2009; REN X, et al., 2017).

Glutathione system acts in cellular defense against ROS in synergy with the enzymatic antioxidant system, the glutathione peroxidase (GPX) and glutathione-S-transferase (GST) (CHAUDHARI R, et al., 2017). In addition, GSH also plays roles on cell signaling and proliferation and metabolism of inflammatory mediators such as leukotrienes and prostaglandins (REN X, et al., 2017). Moreover, still regulates the immune response in diverse infectious etiologies, including malaria and may present a potential protective effect against the evolution of the disease (CHAUDHARI R, et al., 2017).

\section{Placental malaria and oxidative and nitrosative stresses}

Malaria in pregnancy is considered an aggravating factor and it is an important public health problem, being caused in human mainly by $P$. falciparum parasites, however some studies report that infections caused by $P$. vivax can be related to the aggravation of this complication (ROGERSON SJ, et al., 2017). In addition, the term placental malaria is restricted used only for the placental involvement. Previous studies have shown that pregnant women are five times more likely to get malaria when compared to non-pregnant ones, mainly by regulation of the immune response (OLUWAGBEMIGA A, et al., 2018).

The pathogenesis of this complication is initiated when the iRBC (by P. falciparum) start to express in their membranes antigenic surface proteins of the parasite, such as the Plasmodium falciparum erythrocyte membrane protein 1 (PfEMP1), a highly variable protein (encoded by at last 60 different genes in the parasite) that binds to host receptors, such as CD36, ICAM-1, chondroitin sulfate A (CSA), among others. In placental malaria, the PfEMP1 exhibits more affinity to the chondroitin sulfate $A$ (CSA), fixing the iRBC in the endothelium of the vessels of the microcirculation in the intervillous space of placenta (NUNES MC, et al., 2007).

After this, the iRBC are sequestered in the placental vascular space where blood flow is lower, through the interaction of the Plasmodium surface's protein with endothelial cell's proteins, triggering histologic changes in the placenta and obstruction of the placental blood flow with accumulation of inflammatory cells and deposition of fibrin. Pregnant women with successive malaria infections develop a better immune response because they produce antibodies that block the adhesion molecules of infected cells (DJONTU JC, et al., 2016).

The sequestrated iRBC in the placental microcirculation generate the activation of the immune response through the recognition of parasite proteins mainly by resident macrophages and neutrophils, starting the production of cytokines, amplifying the immune response at these sites of the blood flow and generating the oxidative/nitrosative stresses, resulting in lesions in the trophoblast cells, which are responsible for the transport of nutrients and gas exchanges between mother and fetus, generating an imbalance of inflammatory and nutritional imprint, with several adverse effects for the fetus (NERES R, et al., 2008; ROGERSON SJ, et al., 2017). The pathogenesis of the placental malaria can be briefly seen in the Figure 5 . 
Figure 5 - Pathogenesis of the placental malaria. Infected red blood cells (iRBC) express the Plasmodium falciparum erythrocyte membrane protein 1 (PfEMP1), which interacts with endothelial cells in the microcirculation of the intervillous space of the placenta, getting "fixed" (sequestered) and escaping of the blood flow. After this, neutrophils and macrophages are recruited to these locals, producing cytokines and chemokines with posterior activation of the oxidative and nitrosative stresses pathways, producing ROS and RNS and damaging endhotelial barriers, triggering a placental inflammation process.

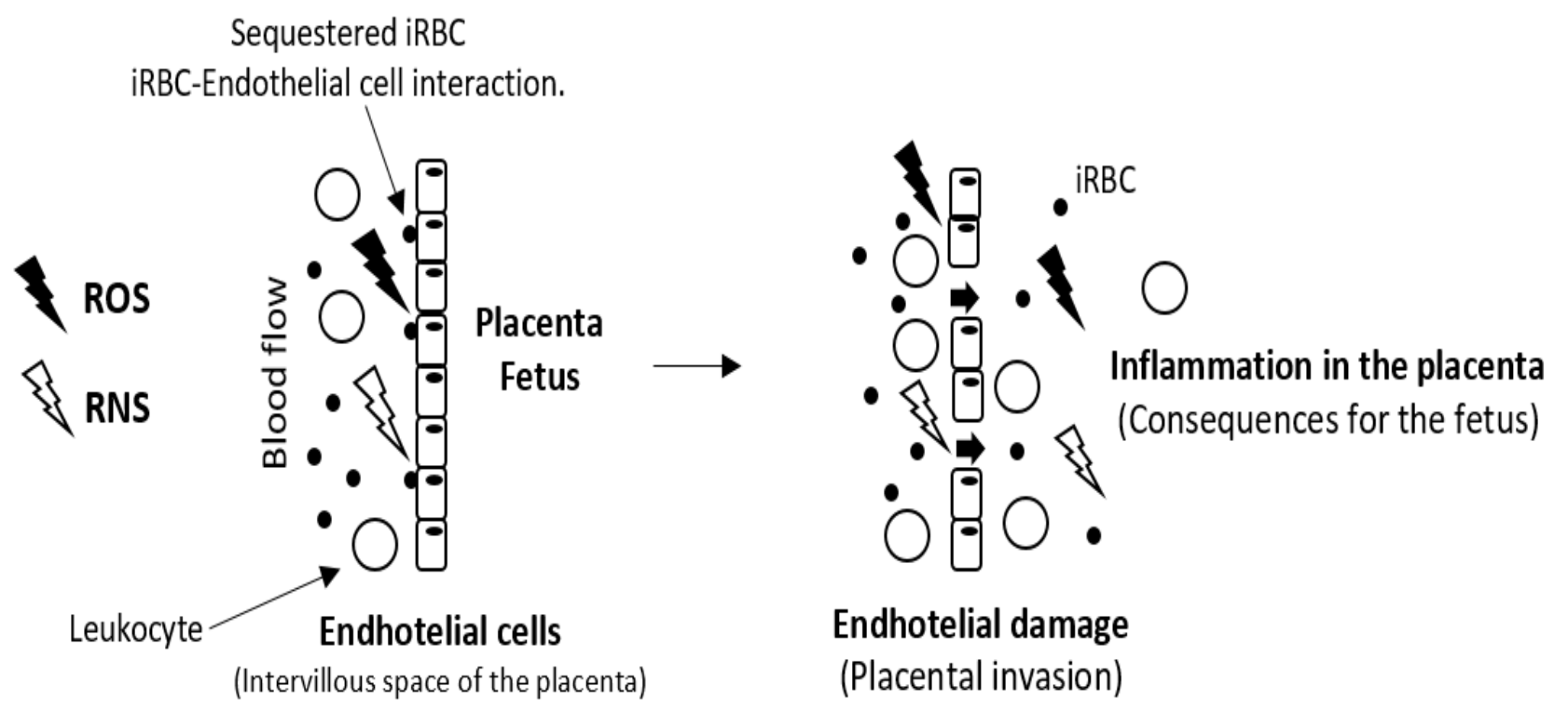

Source: Dantas KLS, et al., 2020.

In this context, the production of ROS and RNS, mainly hydrogen peroxide and nitric oxide, play a deleterious role, since the production of these reactive species are related with the breakdown of the placenta due to lipid and protein peroxidation, causing damage to the integrity of this barrier and allowing the invasion of the parasites with following tissue damage and placental inflammation. Previous histological studies have shown that oxidative stress markers such as levels of lipid peroxidation by measuring malondialdehyde (MDA) are increased in infected pregnant women when compared to infected non-pregnant ones (SHARMA L, et al., 2012; MEGNEKOU R, et al., 2015).

Therefore, it is concluded that the oxidative and nitrosative stresses, especially the enhancement of the production of hydrogen peroxide and nitric oxide, play an essential role in the defense of the organism against Plasmodium-related infections because they act as a microbicidal and inflammatory signaling agent, however, in some cases, as in placental malaria, they can act as an aggravating agent, since ROS/RNS can oxide cellular components that forms the biological barriers, thus, damaging them and making the placental tissue and fetus vulnerable to the actions of the malaria parasite, causing serious consequences to fetus.

\section{Consequences to the fetus}

During pregnancy, women are susceptible to increased Plasmodium infection, which causes an intense infiltration of $\mathrm{RBC}$ in the microvasculature of the placenta, a privileged location for the development of the disease, where the parasite can prevent the immune response (TOBÓN-CASTAÑO A, et al., 2011). Although not yet well understood, it is believed that this susceptibility to malaria during pregnancy may be associated with high levels of steroid hormones, impairing the immune response against the Plasmodium spp. (ROBINSON DP, et al., 2012).

The sequestration of iRBC causes an increase in the infiltration of leukocytes in the interventional spaces of the placenta, provoking the inflammatory response in these places and increasing vascular permeability, leading to placental insufficiency. In this context, the exchange of nutrients between mother and fetus is compromised, causing a series of changes. 
Deficits in the supply of nutrients to fetus result in malnutrition and restriction of intra-uterine growth, impacting the normal development of the fetus and causing a series of changes in the weight of newborns and a high rate of prematurity and stillbirths (TOBÓN-CASTAÑO A, et al., 2011) .

The literature also shows that malaria infection can affect fetal anthropometry, especially the cranial circumference. In addition, it has been associated with some cases of microcephaly (DOMBROWSKI JG, et al., 2017). Other deleterious effects to the fetus caused by placental malaria can be observed, such as the occurrence of abortions, malnutrition, low birth weight, prematurity, delayed uterine growth, low birth weight, maternal death, among others (TAKEM EN, et al., 2013).

\section{FINAL CONSIDERATIONS}

Malaria is still an important public health problem with high morbidity and mortality. It can spread to several organs, triggering an inflammatory response in these tissues and causing cellular damage thus, compromising several vital functions and evaluating for severe malaria, such as cases of placental malaria, where the immune response and the oxidative and nitrosative stresses play important role not only in the defense of the patient, but also in the progression of the disease and invasion of the Plasmodium, since the high production of ROS and RNS causes the peroxidation of lipids, proteins and nucleic acids, causing the breaking of biological barriers of the placenta, causing severe alterations for fetus, among them abortions, malnutrition, low birth weight, prematurity, delayed uterine growth, stillbirths and even maternal death.

\section{REFERENCES}

1. AL-SHAEBI EM, et al. Susceptibility of mice strains to oxidative stress and neurotransmitter activity induced by Plasmodium berghei. Saudi Journal of Biological Sciences, 2017; 25:167-170.

2. BERTOLDO BJ, TERENZI H. Oxidation and Tyrosine Nitration Induce Structural Changes and Inhibits Plasmodium falciparum Falcipain-2 Activity In Vitro. Protein and Peptide Letters, 2016; 23:562-572.

3. BAKIR HY, et al. Cytokine profile of murine malaria: stage-related production of inflammatory and anti-inflammatory cytokines. Biomedical Research, 2011; 32:203-208.

4. BISWAS S, et al. Role of free radicals in human inflammatory diseases. AIMS Biophysics, 2017; 4:596-614.

5. CANLI EG, et al. Response of the antioxidant enzymes of the erythrocyte and alterations in the serum biomarkers in rats following oral administration of nanoparticles. Environmental Toxicology and Pharmacology, 2017; 50:145-150.

6. CHAUDHARI R, et al. Glutathione and thioredoxin systems of the malaria parasite Plasmodium falciparum: Partners in crime? Biochemical and Biophysical Research Communications, 2017; 488:95-100.

7. CORBETT Y, et al. Interplay between Plasmodium falciparum haemozoin and I-arginine: implication for nitric oxide production. Malaria Journal, 2018; 17:1-13.

8. DJONTU JC, et al. Impact of placental Plasmodium falciparum malaria infection on the Cameroonian maternal and neonate's plasma levels of some cytokines known to regulate $\mathrm{T}$ cells differentiation and function. Malaria Journal, 2016; $15: 561$.

9. DOMBROWSKI JG, et al. Association of malaria infection during pregnancy with head circumference of newborns in the Brazilian Amazon. JAMA Network Open, 2019; 2:e193300.

10. ELZEIN F, et al. Pulmonary manifestation of Plasmodium falciparum malaria: Case reports and review of the literature. Respiratory Medicine Case Reports, 2017; 22:83-86.

11. FORMAN HJ, et al. Glutathione: overview of its protective roles, measurement, and biosynthesis. Molecular Aspects of Medicine, 2009; 30:1-12.

12. GLORIEUX G, CALDERON PB. Catalase, a remarkable enzyme: targeting the oldest antioxidant enzyme to find a new cancer treatment approach. Biological Chemistry, 2017; 398(10): 095-1108.

13. HAWKES M, et al. Nitric oxide for the adjunctive treatment of severe malaria: hypothesis and rationale. Medical Hypotheses, 2011; 77:437-444.

14. HERNANDEZ SD, et al. Redox Regulation of the Superoxide Dismutases SOD3 and SOD2 in the Pulmonary Circulation. Advances in Experimental Medicine and Biology, 2017; 967:57-70.

15. HIRST DG, ROBSON T. Nitric oxide physiology and pathology. Nitric Oxide, 2011; 704:1-13.

16. ISLAM BU, et al. Pathophysiological Role of Peroxynitrite Induced DNA Damage in Human Diseases: A Special Focus on Poly (ADP-ribose) Polymerase (PARP). Indian Journal of Clinical Biochemistry: IJCB, 2015; 30:368-385.

17. LAPOUBLE OMM, et al. Situação epidemiológica da malária na região amazônica brasileira, 2003 a 2012. Revista Panamericana de Salud Pública, 2015; 38:300-306.

18. MEGNEKOU R, et al. Impact of placental Plasmodium falciparum malaria on the profile of some oxidative stress biomarkers in women living in Yaoundé, Cameroon. PloS One, 2015; 10:e0134633.

19. MUBARAKI MA, et al. Oxidative stress and genes regulation of cerebral malaria upon Zizyphus spina-christi treatment in a murine model. Microbial Pathogenesis, 2017; 107:69-74. 
20. NERES R, et al. Pregnancy outcome and placenta pathology in Plasmodium berghei ANKA infected mice reproduce the pathogenesis of severe malaria in pregnant women. PloS One, 2008; 3:e1608.

21. NUNES MC, SCHERF A. Plasmodium falciparum during pregnancy: a puzzling parasite tissue adhesion tropism. Parasitology, 2007; 134(13): 1863-1869.

22. OLUWAGBEMIGA A, et al. Prevalence of malaria in pregnant women attending antenatal clinic in primary health centres in Lagos. South West, Nigeria. Journal of Advances in Medicine and Medical Research, 2018; 25:1-9.

23. PERCÁRIO S, et al. Oxidative stress in malaria. International Journal of Molecular Sciences, 2012; 13:16346-16372.

24. PERKINS DJ, et al. Severe malarial anemia: innate immunity and pathogenesis. International Journal of Biological Sciences, 2011; 7:1427.

25. PIZZINO G, et al. Oxidative stress: Harms and benefits for human health. Oxidative Medicine and Cellular Longevity, $2017 ; 2017: 8416763$.

26. POILOS TL, LI H. Nitric oxide synthase and structure-based inhibitor design. Nitric Oxide, 2017; 28(63): 68-77.

27. RAMANI S, et al. Detection of chloroquine and artemisinin resistance molecular markers in Plasmodium falciparum: A hospital based study. Tropical Parasitology, 2016; 6:69.

28. RANI V, et al. Oxidative stress and metabolic disorders: Pathogenesis and therapeutic strategies. Life Sciences, 2016; 148:183-193.

29. REN X, et al. Redox signaling mediated by thioredoxin and glutathione systems in the central nervous system. Antioxidants \& Redox Signaling, 2017; 27:989-1010.

30. ROBINSON DP, KLEIN SL. Pregnancy and pregnancy-associated hormones alter immune responses and disease pathogenesis. Hormones and Behavior, 2012; 62:263-271.

31. ROGERSON SJ. Management of malaria in pregnancy. Indian Journal of Medical Research, 2017; $146(3)$ : 328.

32. SHARMA L, et al. Plasmodium berghei: influence of infection on the oxidant and antioxidants levels in pregnant BALB/c mice. Experimental Parasitology, 2012; 131:215-222.

33. SIES $\mathrm{H}$. Hydrogen peroxide as a central redox signaling molecule in physiological oxidative stress: oxidative eustress. Redox biology, 2017; 11:613-619.

34. SOBOLEWSKI P, et al. Nitric oxide bioavailability in malaria. Trends in Parasitology, 2005; 21:415-422.

35. TAKEM EN, D'ALESSANDRO U. Malaria in pregnancy. Mediterranean Journal of Hematology and Infectious Diseases, 2013; 5:e2013010.

36. TOBÓN-CASTAÑO A, et al. Retardo no crescimento intrauterino, baixo peso ao nascer e prematuridade em recémnascidos de grávidas com malária, na Colômbia. Revista da Sociedade Brasileira de Medicina Tropical, 2011; 44:364370 .

37. TURK BR, et al. Antioxidant capacity and superoxide dismutase activity in adrenoleukodystrophy. Jama Neurology, $2017 ; 74: 519-524$.

38. WARNATSCH A, et al. Reactive oxygen species localization programs inflammation to clear microbes of different size. Immunity, 2017; 46:421-432.

39. WORLD HEALTH ORGANIZATION. World malaria report 2015. Genebra, 2015; 280p. 